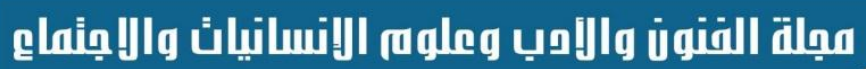 \\ Journal of Arts, Literature, Humanities \\ and Social Sciences
}

ISSN print: 2616- 3810

Volume 48

HALHSS



ISSN online: 2414 - 3383

January 2020

www.jalhss.com

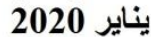

\section{Compulsory License and Patent Protection}

\author{
Hemn Khalid Ali \\ College of Law - Salahaddin University-Erbil - Iraq \\ Email:hemn.ali@su.edu.krd
}

\begin{abstract}
The encouragement of patent holders to continue their creativity requires protection for their inventions by the law; this can be achieved by preventing the use of their intellectual product without their consent. On the other hand, the inventors may abuse this right for their personal interests. Thus, in particular situations, for the public's interest there must be an allowance to use their inventions. Furthermore, there are conflicting interests between developed and developing countries with regard to allowance and prevention of compulsory license. Hence, it has been regulated by a number of international conventions. Compulsory license is regarded as a solution to keep balance between the patent owner's right and the issuance of compulsory licenses, especially in pharmaceutical sector. Nevertheless, it is not an ideal settlement.
\end{abstract}

Keywords: Compulsory License, Paris Convention, TRIPS, Patent Protection 


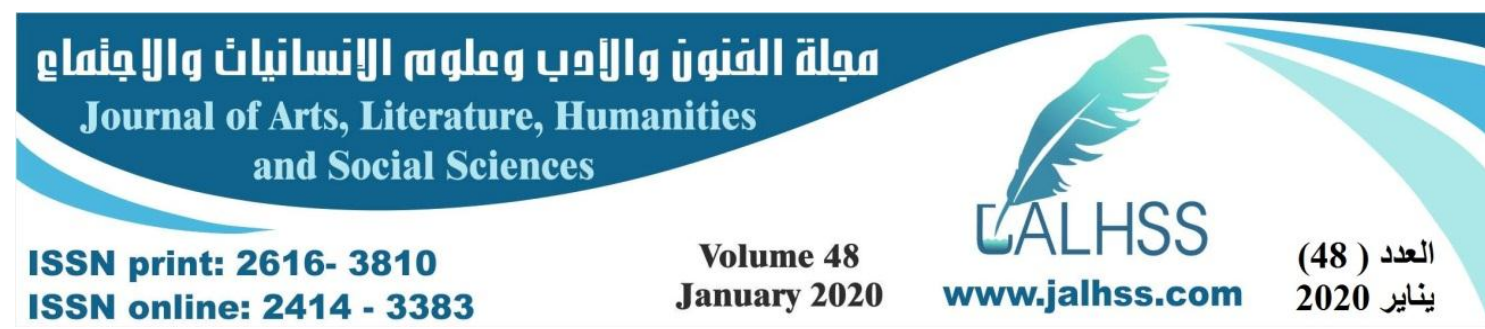

\section{Introduction}

Patent holders rights have been protected by patent laws. There are safeguards in patent system to guarantee that these rights are not abused and not misuse by right holders. One of the safeguards is compulsory licensing. According to compulsory licensing, a third party has right to exploit the invention without patent s owner assent pursuant to terms and conditions determined by the government (Abbas \& Riaz, 2013, 482). In this paper compulsory license and Paris Convention as main steps to deal with intellectual property as a universal issue will be clarified. Further, the TRIBS as an international intellectual property treaty will be highlighted. Moreover, the balance between of patent owner and the issuance of compulsory licenses will be evaluated. Further, anti-HIV drugs as the main problem in this field will be clarified. Finally some shortcomings and recommendations with regard to compulsory license will be determined.

\section{1- Compulsory License and The Paris Convention}

Pursuant to the WTO definition, "compulsory licensing is when a government allows someone else to produce the patented product or process without the consent of the patent owner. It is one of the flexibilities on patent protection included in the WTO's agreement on intellectual property - the TRIPS (Trade-Related Aspects of Intellectual Property Rights) Agreement (http://www.wto.org/english/tratop_e/trips_e/public_health_faq_e.htm).

The Paris Convention was designed to harmonize intellectual property amongst the various countries as far as possible. Pursuant to the Paris Convention 1883 each country of the Union has been allowed to enact legislation to grant compulsory license so as to prevent abuses may result from the exercise of the exclusive rights conferred by the patent (Paris Convention, Article 5A (2)).

Compulsory license may be grant for any invention due to failure to work or for insufficient working after the expiration of grace period. This duration is four years from the date of filing the patent application or three years from date of the grant of the patent. It may be refused by owner of patent in according to a justification if it has been proved inaction was legitimately. Moreover, compulsory licenses must be non-exclusive (Paris Convention, Article 5A (4)).

The failure to work an invention cannot lead to forfeiture of the paten unless in situations of the grant of a compulsory did not cause sufficient prevention to abuse patent. In this circumstance, lawsuit must be instituted no sooner than two years after the compulsory license was granted (Paris Convention, Article 5A (3)). 




\section{2- Criticisms of the Paris Convention}

However, the Paris Convention was deemed an essential step to deal with intellectual property on a universal level but it was criticized due to lack of substantive standard for intellectual property and member countries were free to structure their domestic intellectual property legislation how they want. For instance, there was not comprehensive definition for patent matter. It means that the Paris Convention did not care about keeping balance between of patent owner and the issuance of compulsory licenses because more freedom had granted for states to construct their legislation. Moreover, another criticism was faced the Paris Convention was lack of enforcement capabilities.

\section{3- Compulsory License and TRIPS}

In 1994, TRIPS was adopted by WTO which is regarded as the best international intellectual property treaty (Halajian, 2013, 1196). Even the term "compulsory licensing" does not appear in the TRIPS Agreement; instead, the phrase "other use without authorization of the right holder" appears in the title of Article 31. While it is assumed that Article 31 in (TRIPS) agreement improve flexibility, it forces stricter condition on compulsory licensing so it has been described as paradoxically restrictive (Carvalho, 2011, 427).

Pursuant to Article 31, governments in developing and least developed countries have right to use the subject-matter without license of the patent owner so as to produce this subject-matter by another manufacturer in certain stipulated situation. It has stated that before such use the proposed user has made efforts to achieve authorization from the patent owner on "reasonable commercial terms and conditions" and those efforts have not been successful within a "reasonable period of time" (TRIPS art.31 (b).). It means, firstly the proposed user must try to achieve a license from the patent owner voluntarily.

In other words, the compulsory license must not be forced until the negotiation reached deadlock. There is shortcoming in Article 31 (b) which is not explained the term "reasonable period of time", the patent owner has opposite view towards reasonable term. For instance, recently Thailand has imposed a compulsory license after months of negotiation but the patent owner said he did not expect compulsory license will be imposed because he did not know the reasonable period of time finished (Ho, 2011, 133- 134).

On the other hand, the requirement of negotiation can be conceded in a number of situations, such as national emergency, extreme urgency and public noncommercial use. In these circumstances a patent owner has not any opportunity to make discussion about imposing compulsory license as long as he is notified. 




However, pervious negotiation is waived, other requirements still remain as a patent holder rights like remuneration (TRIPS art.31 (b)). In terms of the scope and duration in case of compulsory license is restricted to "the purpose for which it was authorized" (TRIPS art.31 (c)).

\section{4- New Developments in Compulsory License}

According changes in the South African patent law and expand an interpretation of concept of compulsory license, the South African states has authority to produce patented pharmaceutical and import cheaper generic medicines from overseas. The pharmaceutical companies and the United Stated reacted instantly through imposing economic sanction. The international response reflected by the World Trade Organization in the Public Health Declaration in November 2001.

In this Declaration has stated that TRIBS does not make prevention of taking measures to protect public health (MacQueen, Waelde, Laurie \& Brown, 2011, 390391). It asserts that the TRIPS Agreement should be construed and performed in order to protect public health and develop access to medicines for all. In addition, each member is entitled to grant compulsory licenses and freedom to decide in which situation compulsory licenses can be granted and each of them has right to determine what comprise national emergency or extreme urgency and public health crisis (Gupta, 2010, 359). Moreover, the Doha Declaration affirmed that all member states have right to use compulsory licenses to gain generic drugs as a respondent to health needs. Further, the transitional period was extended by the WTO for developing countries to perform the TRIPS pharmaceutical patent provisions to 2016 (Lee, 2013, 1398).

It is obvious, Article 31 (f) in TRIPS Agreement, It has been clarified that compulsory license is designed to supply the domestic market. Under Article 31 in TRIPS Agreement compulsory license for expert is not allowed. As a result if the production was allowable under compulsory license, they countries which suffer from insufficient or no manufacturing capacity in the pharmaceutical field, cannot take benefits from compulsory license (MacQueen, Waelde, Laurie \& Brown, 2011, 391).

\section{5- $\quad$ LDC Problem}

The attempts by NGOs and human rights activist gained success to draw attention of the world community to focus on specific problems which faced undeveloped countries which is called LDCs (lacking manufacturing capacity) (Abbas \& Riaz, 2013, 483). WTO members recognized this problem so they asked for an expeditious solution by staying" we recognize that WTO Members with insufficient or no manufacturing capacities in the pharmaceutical sector could face difficulties in 


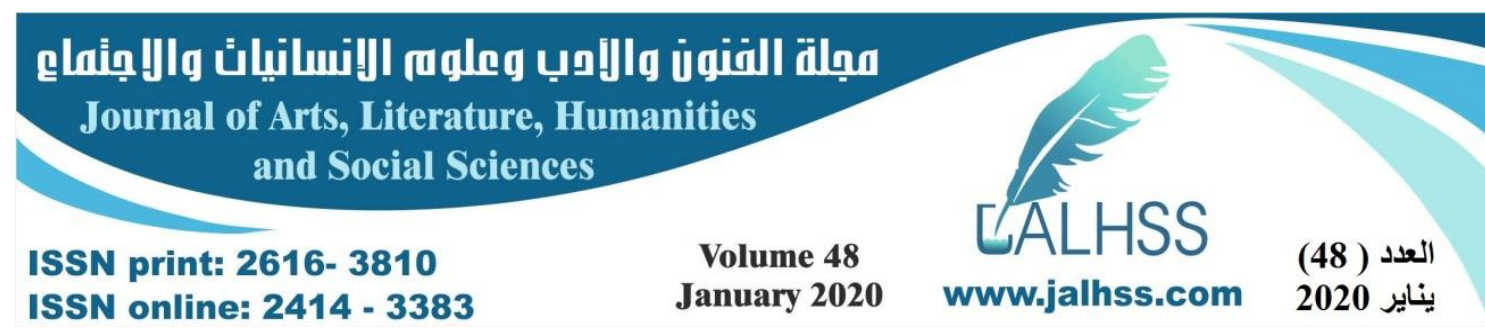

making effective use of compulsory license under TRIPS Agreement. We instruct the Council for TRIPS to find an expeditious solution to this problem and to report to the General Council before the end of 2002" (Tehofou, 2011, 27).

\section{6- $\quad$ New Changes in Compulsory License's Concept}

Consequently, after two years, the implantation of the paragraph 6 was diagnosed as a solution. The Decision on the Implementation of the Doha Declaration on the TRIPS Agreement was adopted on 30 August 2003. The Doha Ministerial Conference resolved this problem in interest of countries which have not capacity to manufacture pharmaceuticals. Consequently, the provision of domestic production in TRIPS Article 31(f) is changed and some conditions are stipulated. Firstly, an application must be apply for the WTO by the importing country. Secondly, the WTO must be notified about the compulsory license which granted in the exporting country and the quantity must be limited with the needs of the importing country. Finally, Products must be distinguished by particular labelling and marking and knowledge must be published through the internet. In other words, Member states can import medicines needed from other countries after making requirement steps (Kumaw, 2010, 138-139).

\section{7- $\quad$ The Scope of Using Compulsory License}

A cases in which compulsory licenses might be granted as exceptions are not limited. As far as national emergency is concerned, it is not defined also TRIPS does not determine how a nation can assess whether an emergency situation exist or no. Moreover, the most controversial phrase is "public non-commercial use" which is undefined in TRIPS. Consequently, the TRIPS agreement does not specifically list the situations that might be used as a justification to impose compulsory licensing because the grounds for compulsory licensing does not restricted in TRIPS. Pursuant to this clarification, a member states have freedom to determine the grounds as an excuses to compulsory license is necessary in other industries (Ho, 2011, 134- 135).

On the other hand, there are opposite arguments against extending of scope of compulsory license even in scope of pharmaceuticals industry. For instance, In spite of many strong evidences approved the seriousness of chronic diseases special challenges face developing countries in using compulsory license to overcome chronic diseases. Firstly, the terms of epidemics and infectious diseases were used in the Doha Declaration without mention to chronic diseases. Secondly, there is a misunderstanding that chronic diseases only affect rich countries so it does not need to provide medicine at affordable price. Thirdly, non-pharmaceutical means can be used to combat chronic diseases. Finally, expansion the range of compulsory licenses 


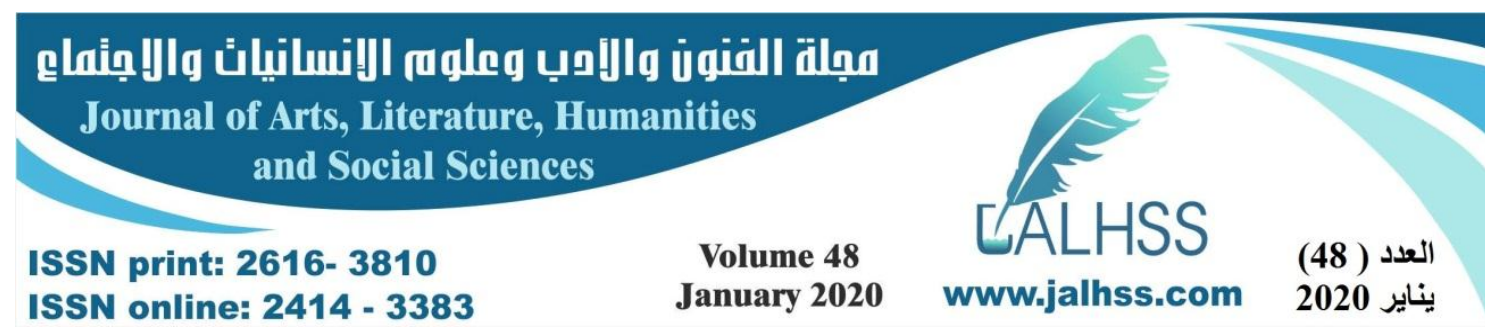

to include chronic diseases may face stronger opposition from pharmaceutical companies because it will cause a reduction of profit industry (Halajian, 2013, 12181219).

\section{8- Developing Countries and Patent Protection}

The TRIPS Agreement is regarded as an important means in the aspect of intellectual property protection. According to its provisions, states which do not protect pharmaceutical patents should make amendment in their nation's laws in order to comply with TRIPS. The protection of pharmaceutical patents and application of TRIPS is not easy task by virtue of variation of national regimes (Jasmila, 2013, 11). The interests of developing country may be not with patent protection due to the various reasons. Firstly, Piracy provides accessing needed goods and service at affordable prices for developing and undeveloped countries. Secondly, reducing unemployment, the local industries to produce counterfeit goods may employee many of workers in developing countries. Thirdly, reaching to intellectual property in developed centuries is too important to advance science and technology in developing countries. Finally, over $80 \%$ of patents in developed and undeveloped countries possess by nationals in developed countries. Thus, the governments of these countries do not desire to spend large amounts in developing effective administrative technique to impose compulsory license on citizens of advanced states.

It can be conclude due to the interests of developing countries issuance of compulsory licenses outweigh rights of patent owner (Abbas, 2013, 254).

Interests of developing countries has reflected in their legislations, for instant, pursuant to Patent Act in Thailand 1979, compulsory license can be issued to provide any service for public consumption or to prohibit or reduce a server shortcoming of food and drugs. Patent law in Thailand makes more facilitation for using TRIBS flexibility by reduce red-tapism. Any ministry, bureau or department of government is permitted to exercise compulsory license (Gupta, 2010, 362). Also in India, section: 8 of the Act talks about compulsory license, the patent holder cannot keep the invention without working on it. Further, any interested person can request compulsory license if patent holder does not take advantage from the invention and after three years of granting and sealing of the patent anyone can sought compulsory license. In other words, it can be concluded, in India, compulsory license may be sought in these circumstances. Firstly, the reasonable demands of the public with indicate to the patented invention have not been satisfied. Secondly, the public cannot reach the patented invention at a reasonably affordable price. Thirdly, the patented invention is not taken advantage or worked in India, fourthly, all other avenue has been exhausted 




to work on the invention by the applicant, finally " the court is satisfied that a situation has aroused where in compulsory license is the only method is met on the invention"(Sreenivasulu, 2013, 301).

Generally the limitation of funds medical treatment in the developing countries is one of factors to resort a compulsory license. For instance, even HIV/AIDS is ravaging the population In Africa; there is a low budget for every person which is less than ten dollars per capita for medicines annually (Borowski, 2009, 290). Moreover, five million people infected with HIV/AIDS. Believing that TRIPS allowed them to resort compulsory license is a best means to more competition and to provide an affordable drug prices because HIV/AIDS is a nation crises (Lang, 2004, 336). Consequently, South Africa issued the Medicines and Related Substances Control Act, which permitted Local African companies to produce HIV/AIDS drugs pursuant to compulsory license.

\section{9- Developed Countries and Compulsory License}

By contracts, developed countries are very much concerned about patent protection because investment in research and development is one of the means to progress and economic development. Moreover, compulsory license may decrease incentive to innovate and create new products. In addition, another weak point in products under compulsory license is related to the inferior quality because the not approved generics may include numerous dangerous impurities (Abbas, 2013, 255). Even about the point which connected to compulsory license and innovation there is a great doubt whether compulsory license has a negative impact on innovation or not. Until now, there is not any data prove that compulsory licensing has a passive influence in innovation and reduce research and development in developed and developing countries (Junior, 2005, 8-9).

This attitude of developed countries has reflected in their patent laws. For example, The United States has endorsed compulsory licensing and giving such a license in the United States connected with the very special circumstances. Limitations are placed on the circumstances where governments can issue compulsory licensing of patent. In other words in very special cases can be resorted for a Compulsory license in the United States. The reason is companies spent the billions of dollars on the research and development necessary for innovation and production; due to compulsory licensing will be unable of recouping the amount of money (Tyler, 2014, 463). The United States has supported the pharmaceutical industry, which regarded as an opposition to compulsory licensing and parallel importation of drugs according to patent law in other countries.

According to Section 48 of the UK Patents Act, any person to the Comptroller 




of Patents can apply for a compulsory license at any time after the expiration of three years from the date of grant of the patent for relief. License will not be granted by the UK Patent Office unless "prior to his making an application for a license, the applicant has made efforts to obtain a license from the proprietor on reasonable commercial terms and conditions and his efforts have not been successful within a reasonable period". Moreover, the Comptroller must take account some points when he use discretion whether or not to grant a compulsory license. These points connected with "the nature of the invention, the time which has elapsed since grant of the patent, and the action of the proprietor or licensee in developing full use of the invention, the ability of the applicant to work the invention to the public advantage and the risks to be undertaken by the applicant in providing capital and working the invention" (Mccall, Epping \& Thompson, 2013).

Generally, due to the provisions connected with remuneration and previous negotiation with patent holder it can be concluded some balances between imposing compulsory licensing and protection of patent holder rights under TRIBS. The allowance of compulsory licensing under TRIBS demands a several requirements and conditions. In cases of national emergencies and government use compulsory license need negation with patent holder. In addition, adequate remuneration must be granted patent holder and it has been affirmed that the use of patent should non-exclusive and it is only permitted to supply domestic market (Jasmila, 2013, 7).

Moreover, the balance between of patent owner and the issuance of compulsory licenses can be seen generally in Article 8(1) and Article 27(2). Article 8(1) elucidates through the drafting of TRIPS public health was the subject of concern. In Article 8 a number of consideration are mentioned, they must be taken account when a country adopts intellectual property policy and when patent rights exceptions have been created. These considerations are protection of public health and nutrition, promotion of the public interest in sectors of vital importance to their socio-economic, protection against unreasonable restrained trade and protection against that adversely affect the international transfer technology agreement. Article 27(2) excludes patentability of inventions that are "necessary to protect the order public or morality" including those inventions that protect human life or health (Halajian, 2013, 1197- 1198).

\section{0- Obstacles Facing TRIPS}

On the other hand, a number of factors have been determined as the problems and barriers to successful use of TRIPS. Consequently, these factors cause to do not achieve its complete purposes. As a result, the dual aims of balancing intellectual rights with reach to important medicines have not been wholly attained. Firstly, before issue the compulsory license, there are a several complicated procedural must be done. However, a developing country is eventually successful in allowing a 


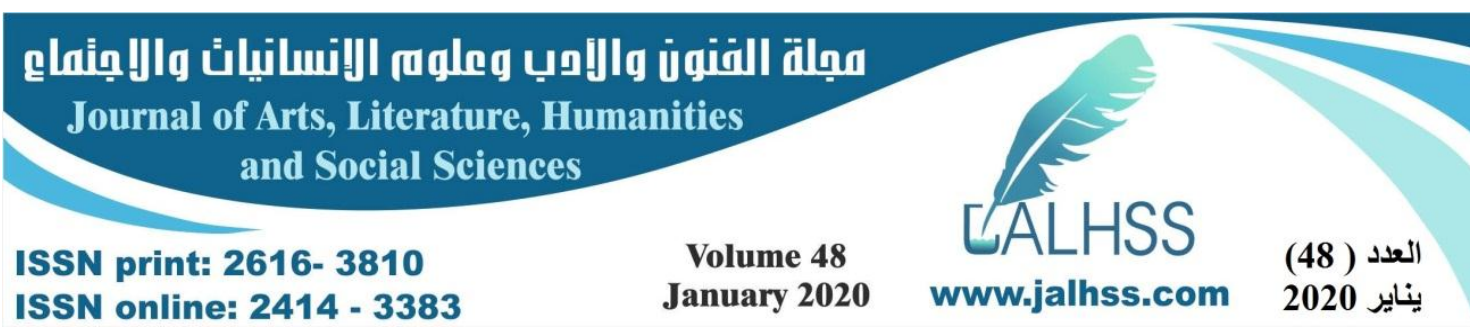

compulsory license, but the jurisdiction review may hinder from producing generic version. Moreover, the paragraph 6 Decision is not simplification procedure and takes a long time, costly and seldom has been used. Further, this paragraph has not been enacted in domestic legislation in many countries (Halajian, 2013, 1202- 1203). Canada was the first country resorted to using paragraph 6 when Rwanda demanded to import the HIV-drug TriAvir from the Canadian company Apotex, On 19 July 2007 (Royle \& Wessing, 2008, 20).

Apotex criticized this mechanism of the 'unnecessarily complex' system and 'adequately represent the interests of those who require treatment'. Apotex concluded that the mechanism must be changed in order to be more effective. Moreover, it is not easy to persuade countries to inform the WTO of their need to import and giving two years as a maximum time is not sufficient to recoup the investment of producing a generic drug (Kumaw, 2010, 139- 140).

Secondly, Article 30 after fifteen years in force, just a small number of countries have issued compulsory licenses. Under the 2003 Paragraph 6 Decision, one country has issued compulsory licensing. Further, TRIPS has not effective influence to decrease the prices of medicines because the quantities of each compulsory license are predefined (Halajian, 2013, 1205-1206).

Thirdly, another barrier for keeping balance is related to ambiguities in the interpretation of TRIPS. The Doha Declaration clarified that every states has "the right to determine what constitutes a national emergency or other circumstance of extreme urgency" in order to give compulsory license. The flexible range of compulsory licenses causes over-use and excessive abuse of compulsory license. Even various interpretations reflected in the sort of pharmaceutical products which intended for compulsory license (The Doha Declaration paragraph 5 (c)).

The final shortcoming is connected with limitations inherent in developing countries. Developing countries if they want to take benefits from RTIPS flexibilities, there are a several requirements such as legal sophistication, intergovernmental coordination and technical expertise. Generally, developing governments do not have these requirements. In addition, developing countries suffer from inability to diagnose diseases. Consequently, it makes barriers to determine appropriate quantities and kinds of drug in compulsory license (Halajian, 2013, 1211- 1212).

The main excuse for protection patent rights is to recoup large research and development costs (R\&D). This form of recouping (R\&D) costs by profit should be modified and reducing the prices should be handled through funding and incentives. Public-private partnerships which assist financing and product development might assist encourage efficiency, access, innovation, and information sharing. Partnership efforts can be used as substitution sources of funding $R \& D$ instead of expansion the 


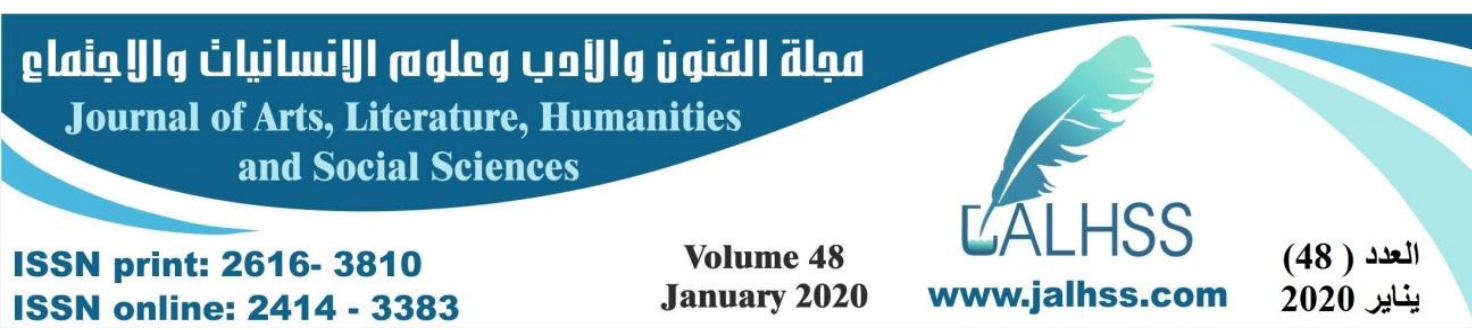

scope of compulsory licenses to provide lower drug prices and raise access.

Moreover, the scope of compulsory should be defined better; limitation of its scope will increase legitimacy also better instruction will prevent misuse of compulsory license. Therefore TRIBS should be amended in order to achieve more active role in compulsory license rather than giving complete discretion on the national parties. Further, article 31(b) in TRIBS agreement should be modified to request good-faith prior negotiations even during a public health emergency. This may decrease the onus and quantity of cases that reach the proposed WTO panel (Halajian, 2013, 12211224).

\section{Conclusion}

The interests of countries outweigh the concept of how the balance between of patent owner and the issuance of compulsory licenses can be achieved. Even some points have been determined as excuses for keeping the balance between of patent owner and the issuance of compulsory licenses like remuneration and pervious negotiation, but there are many factors has been indicated as a reason for frailer to make balance between patent owner and the issuance of compulsory licenses especially in pharmaceutical sector. These factors related to complicated procedural requirements, actual use of compulsory licensing, definitional ambiguities and ambiguities in scope and limitations inherent in developing countries. in order to reach a modern form of compulsory license and provide a balance between patent owner and issuance of compulsory license some amendments are required in terms of using this new model to recoup $R \& D$ costs pharmaceutical, making better definition and restrict scope of compulsory license and article 31(b) in TRIBS agreement should be modified to request good-faith prior negotiations even during a public health emergency.

\section{References}






Journal of Arts, Literature, Humanities

and Social Sciences

ISSN print: 2616- 3810

Volume 48

ISSN online: 2414 - 3383

January 2020

\section{Books:}

1- Carvalho. N. (2011). the TRIBS Regime of Patent Rights, $3^{\text {rd }}$ ed, Kluwer law International, the Netherlands.

2- Ho, Cynthia M.,(2011), Access to Medicine in the Global Economy: International Agreement on Patents and Related Rights, Oxford University Press, New York.

3- MacQueen. H, Waelde. C, Laurie. G \& Brown. A. (2011). Contemporary Intellectual Property Law and Policy, $2^{\text {nd }}$ ed Oxford University Press, the United States.

4- Sreenivasulu N.S. (2013). Law Relating to Intellectual Property, Pattridge India, India.

\section{Articles:}

1- Abbas. M. (2013). Pros and Cons of Compulsory Licensing: An Analysis of Arguments, International Journal of Social Science and Humanity, Vol. 3, No. 3. http://www.ijssh.org/papers/239-D00013 .pdf

Abbas. M \& Riaz. S, March. (2013). Evolution of the Concept of Compulsory Licensing: a Critical Analysis of Key Development before and After Trips, Vol. 4 No.

2. http://www.savap.org.pk/journals/ARInt./Vol.4(2)/2013(4.2-50).pdf

2- Borowski. S. ( 2009). Saving Tomorrow from Today: Preserving Innovation in the Face of Compulsory licensing, Volume 39.

http://diginole.lib.fsu.edu/cgi/viewcontent.cgi?article=1127\&context= fsulr

3- Gupta. R. (2010). Compulsory licensing under TRIPS: How Far it Addresses Public Health Concern in Developing Nations, Journal of Intellectual Property Rights, Volume 15, pp. 357- 363.

http://nopr.niscair.res.in/bitstream/123456789/10211/1/JIPR\%2015(5)\%20357-363 .pdf

4- Halajian. D. (2013). Inadequacy of Trips and the Compulsory License: Why Broad Compulsory Licensing is not a Viable Solution to the Access to Medicine Problem,

http://practicum.brooklaw.edu/sites/default/files/print/pdfs/journals/brooklyn- journalinternational-law/volume-38/issue-3/bjil_v38iii_5.pdf

5- Jasmila. I. ( 2013). Licensing of Pharmaceutical Patents in developing countries.

6- Junior. A, 2005, Compulsory Licensing and Access to Medicine in Developing Countries, Poverty and the International Order, Panel 5: SELA.

http://www.law.yale.edu/documents/pdf/Compulsory_Licensing .pdf

7- Kumaw. S. (2010). Compulsory Licensing Provision under TRIPS: A Study of Roche vs Natco Case in India vis-à-vis the Applicability of the Principle of Audi Alteram Partem, Volume 7, Issue 1, 138- 139. 


 Journal of Arts, Literature, Humanities \\ and Social Sciences}

ISSN print: 2616- 3810

ISSN online: 2414 - 3383

http://www2.law.ed.ac.uk/ahrc/script-ed/vol7-1/kumar .pdf

8- Lang. M, What a Long, and Strange. (2004). "TRIPS" It's been: Compulsory Licensing from the Adoption of TRIPS to the Agreement on Implementation of the Doha Declaration.

http://repository.jmls.edu/cgi/viewcontent.cgi? article $=1055 \&$ context $=$ ripl

9- Stacey B. Lee. (2013).Can Incentives to Generic Manufacturers Save the Doha Declaration Paragraph 6, GEORGETOWN JOURNAL OF INTERNATIONAL LAW, Vol. 44.

https://www.law.georgetown.edu/academics/lawjournals/gjil/recent/upload/zsx00413001387.PDF

10- Tehofou. Y. ( 2011). Compulsory Licensing and Access to Medicines in the TRIPS-Compliant World: Policy Options for Anti-HIV Drugs in Sub-Sahara Africa. https://helda.helsinki.fi/bitstream/handle/10138/25952/papa.pdf?sequence $=1$

11- Tyler. N. (2014). Patent Non-use and Technology Suppression: The Use of Compulsory Licensing to Promote Progress.

http://scholarship.law.upenn.edu/cgi/viewcontent.cgi?article=1548\&context=penn_la W_ review

\section{Website:}

1- Mccall. C, Epping. M. (2013). Thompson. D, Compulsory licensing of patents, June.

http://www.taylorwessing.com/synapse/ti_compulsorylicensingpatents. html

2- Royle. M and Wessing T. ( 2008). Compulsory licenses and access to medicines - Rwanda experience.

http://www.currentpartnering.com/2008/02/20/compulsory-licenses-and-access-tomedicines-rwanda-experience / $\{5 / 05 / 2014\}$

\section{Others:}

1- The Paris Convention (1883).

2- TRIPS agreement (1994).

3- The Doha Declaration(N.D)

4- Compulsory licensing of pharmaceuticals and TRIPS, WTO, (2006).

5- Patent Protection and Access to HIV/AIDS Pharmaceuticals Sub- Saharan Africa, the International Intellectual Property Institute, (2000).

http://www.wipo.int/export/sites/www/about-ip/en/studies/pdf/iipi_hiv.pdf 